\title{
Xylanases of marine fungi of potential use for biobleaching of paper pulp
}

\author{
Chandralata Raghukumar*, Usha Muraleedharan, V. R. Gaud and R. Mishra \\ *National Institute of Oceanography, Dona Paula, Goa 403 004, India. \\ Marine Biotechnology, Goa University, Taleigao Plateau, Goa 403206.
}

\begin{abstract}
Microbial xylanases that are thermostable, active at alkaline $\mathrm{pH}$ and cellulasefree are generally preferred for biobleaching of paper pulp.. We screened obligate and facultative marine fungi for xylanase activity with these desirable traits.

Several fungal isolates obtained from marine habitat showed alkaline xylanase activity. The crude enzyme from NIOCC isolate \# 3 (Aspergillus niger) with high xylanase activity, cellulase-free and unique properties containing $580 \mathrm{U}$ $\mathrm{L}^{-1}$ of xylanase, could bring about bleaching of sugarcane bagasse pulp by a 60 min treatment at $55^{\circ} \mathrm{C}$, resulting in a decrease of 10 kappa numbers and a $30 \%$ reduction in consumption of chlorine during bleaching process. The culture filtrate showed peaks of xylanase activity at acidic $\mathrm{pH}$ (3.5) and alkaline $\mathrm{pH}$ (8.5). When assayed at $\mathrm{pH} 3.5$ optimum activity was detected at $50^{\circ} \mathrm{C}$ with a second peak of activity at $90^{\circ} \mathrm{C}$. When assayed at $\mathrm{pH} 8.5$ optimum activity was seen at $80^{\circ} \mathrm{C}$. The crude enzyme was thermostable at $55^{\circ} \mathrm{C}$ for at least $4 \mathrm{~h}$ and retained about $60 \%$ of the activity. Gel filtration of the $50-80 \%$ ammonium sulfate precipitated fraction of the crude culture filtrate separated into two peaks of xylanase having specific activities of 393 and $2457 \mathrm{U} \mathrm{mg}^{-1}$ protein. The two peaks showing xylanase activities had molecular masses of 13 and $18 \mathrm{kDa}$. Zymogram analysis of xylanase of crude culture filtrate as well as the $50-80 \%$ ammonium sulphate precipitated fraction showed two distinct xylanase activity bands on native PAGE The crude culture filtrate also showed moderate activities of $\beta$-xylosidase and $\alpha$ L-arabinofuranosidase which could act synergistically with xylanase in attacking xylan. This is the first report showing potential application of crude culture filtrate of a marine fungal isolate possessing thermostable, cellulase-free alkaline xylanase activity in biobleaching of paper pulp.
\end{abstract}

\section{Key Words}

Marine fungi, alkaline, thermostable, cellulase-free xylanase, biobleaching, Aspergillus niger

*Corresponding author Email: lata@nio.org

Telephone: 91-0832-2450480; Fax: 91-0832-2450602 


\section{Introduction}

The paper and pulp industry is a potential source of major pollution, generating large volumes of intensely colored effluent for each metric ton of paper produced. In the production of paper, residual lignin from wood pulp is chemically liberated by using chlorine bleaching. Elemental chlorine reacts with lignin and other organic matter in the pulp forming chlorinated compounds that are extracted with alkali. Only about $40-45 \%$ of the original weight of the wood goes into paper production and therefore the effluent that comes out is rich in organic matter [2]. The effluents have a high BOD and COD, chlorinated compounds measured as adsorbable organic halides, chlorinated lignin derivatives such as chlorolignols, dioxins and sulfur compounds. Some of these compounds are carcinogenic, toxic and recalcitrant to degradation and are known as persistent organic pollutants .

In response to stricter government rules regarding pollution control and public awareness, the paper mills are substituting elemental chlorine bleaching with ozone and oxygen delignification and hydrogen peroxide bleaching. Biobleaching is an important alternative to reduce the use of chlorine and chlorine compounds in the bleaching process. Biological bleaching is carried out using white-rot fungi to degrade residual lignin in the pulp by using ligninolytic enzymes such as manganese peroxidase and laccase or by using hemicellulolytic enzymes such as xylanases [5].

Xylan is the predominant hemicellulose in both hardwoods and softwoods that are used for paper making. The cellulose fibres are protected by lignin and hemicellulose. The bond between lignin and hemicellulose is primarily between lignin and xylan which can be removed by xylanase. Thus xylanase is the most important hemicellulase for this reason. Once this layer of hemicellulose is removed, the lignin layer is easily available for the degradative action of the ligninolytic enzymes [9]. In addition, during chlorine bleaching the exposed lignin layer thus requires a lesser amount of chlorine for achieving the required 
brightness. As a result, reduced amounts of chlorinated compounds of lignin are discharged as effluent, causing less environmental pollution and damage.

For pulp treatment, xylanase must be free of cellulase. Xylanase treatment is carried out after the initial alkali extraction of the pulp at high temperatures and therefore the xylanase active at alkaline $\mathrm{pH}$ and stable at high temperature and active in the presence of residual sulfated lignin compounds is highly desirable [28]. The effluent discharged after alkaline extraction of wood pulp containing residual sulfated lignin is called black liquor. The pulp going for further enzymatic treatment contains some traces of this black liquor and might be inhibitory to the enzyme. Therefore, xylanase active in the presence of trace amounts of black liquor is desirable [28].

A few terrestrial fungi having cellulase-free alkaline xylanase activity are reported [ 3 and references therein]. The use of xylanases derived from fungi occurring in the alkaline $\mathrm{pH}$ environment of marine habitats has received little attention. Our objective was therefore to explore the potential of these fungi as a source of alkaline xylanases suitable for use in the biobleaching of paper pulp.

\section{Material and Methods}

Isolation and initial screening of fungi

Fungi were obtained from detritus of decaying mangrove leaves and other plant parts from the mangrove swamps of Chorao Island, Goa, India and from calcareous material from $850 \mathrm{~m}$ depth in the Bay of Bengal. Isolation of fungi was carried out as described earlier by surface sterilization of detritus using $0.5 \%$ sodium hypochlorite solution for $2 \mathrm{~min}$, followed by two washings with sterile sea water [22]. The detritus was plated on corn meal agar medium (Himedia Pvt. Ltd, Mumbai) prepared with half strength sea water and supplemented with $0.05 \mathrm{~g}$ of streptomycin sulfate and 10,000 units of sodium benzyl penicillin in $100 \mathrm{ml}$ of medium to inhibit bacterial growth. Fungi thus obtained were initially screened for xylan-degrading activity by growing them on basal medium containing $1 \%$ oat spelts xylan (Sigma Chemical Co., St Louis, MO, U.S.A.) at $28-30^{\circ} \mathrm{C}$. The basal medium contained the following ingredients $\mathrm{L}^{-1}: 2 \mathrm{~g} \mathrm{KH}_{2} \mathrm{PO}_{4}, 1.45 \mathrm{~g}$ 
$\mathrm{MgSO}_{4} .7 \mathrm{H}_{2} \mathrm{O}, 0.132 \mathrm{~g} \mathrm{CaCl}_{2} .2 \mathrm{H}_{2} \mathrm{O}, 1 \mathrm{mg}$ thiamine- $\mathrm{HCl}, 28 \mathrm{ml}$ of $1.2 \mathrm{mM}$ ammonium tartrate and $18 \mathrm{~g}$ agar. The medium was prepared with distilled water and adjusted to $\mathrm{pH} 4.5$ with $20 \mathrm{mM}$ sodium acetate buffer or to $\mathrm{pH} 8.5$ with 20 $\mathrm{mM}$ glycine- $\mathrm{NaOH}$ buffer as required. As these isolates were obtained from marine habitats, production of xylan-degrading enzymes under marine conditions was tested, wherein the same media were prepared in natural half-strength sea water at a salinity equivalent to 15 parts per thousand (which is the average salinity in mangrove swamps) or 30 parts per thousand for growing the deep sea isolate. Clearance zones produced around the fungal colonies in these media identified the isolates as xylanase positive [14]. The fungi were identified using conventional taxonomic identification keys [7, 17].

Production of xylan-degrading enzyme

The xylan- clearing cultures were grown at $30^{\circ} \mathrm{C}$ up to 7 days in basal medium (pH 4.5 or 8.5 ) containing $1 \%$ oat spelts xylan suspended in natural half strength or full strength sea water or distilled water. Production of xylanase in different xylan sources such as breakfast oats (Commercial preparation), birchwood xylan (Sigma Chemicals, USA) and sugacane bagasse powder (supplied by Pudumjee Paper Mills Ltd, Pune, India) suspended in distilled water or half-strength sea water was also carried out with some of the isolates. The cultures were filtered through Whatman GF/F filters, the filtrate centrifuged at $9,000 \times \mathrm{xg}$ for $15 \mathrm{~min}$ at $5^{\circ}$ $\mathrm{C}$ and the clear supernatants used for enzyme assay. All the assays were carried out in triplicate and repeated at least twice for confirmation. Xylanase from one of the isolates with highest activity was partially purified and characterized. For this purpose, the culture was grown in basal medium prepared with half strength sea water containing oat spelt xylan.

Enzyme assays

Xylanase activity was assayed using 3,5-dinitrosalicylic acid (DNSA) to measure the amount of xylose-equivalent reducing sugars liberated from oat spelts xylan (Sigma Chemicals, USA). The enzyme preparation, containing up to $10 \mu \mathrm{g}$ crude enzyme protein was used for measuring the activity at pH $3.5(50 \mathrm{mM}$ sodium 
acetate buffer) or at $\mathrm{pH} 8.5$ (20 mM glycine- $\mathrm{NaOH}$ buffer) at $50^{\circ} \mathrm{C}$ for $30 \mathrm{~min}$. One unit of activity $(U)$ is defined as the amount of enzyme capable of releasing reducing sugars equivalent to one $\mu$ mole of xylose per minute under the conditions described [21]. was also performed. All results are averages of triplicate measurements. Protein concentrations were measured by the method of Lowry et al. [19] using bovine serum albumin as the standard.

$\beta$-D-xylosidase and $\alpha$-L-arabinofuranosidase activities in the crude culture filtrate of one of the isolates were assayed at $50^{\circ} \mathrm{C}$ at $\mathrm{pH} 4$ in acetate buffer using $p$-nitrophenol- $\beta$-D-xylopyranoside and $p$-nitrophenol- $\alpha-L$-arabinofuranoside, respectively. The reaction was terminated by adding glycine- $\mathrm{NaOH}$ buffer adjusted to $\mathrm{pH} 10.8$ and the absorbance of p-nitrophenol released was read at $430 \mathrm{~nm}$ [27]. One unit of activity $(U)$ is defined as the amount of enzyme capable of releasing one $\mu$ mole nitrophenol per minute under the conditions described. Cellulase activity was determined according to the standards of the International Union of Pure and Applied Chemistry [13].

Effect of black liquor on xylanase activity

Black liquor (obtained from Pudumjee Paper Mills Ltd, Pune, India) at final concentrations of 0.1 and $0.2 \%$ was added to enzyme reaction mixture containing buffer and oat spelts xylan. Xylanase activity was measured after incubation for $30 \mathrm{~min}$ as described above.

\section{Characterization of the enzyme}

For studying the properties of xylanase, the culture filtrates from cultures grown in oat spelts xylan medium prepared in half strength sea water were used. The effect of $\mathrm{pH}$ on the reaction was studied in the presence of different buffers. The buffers used were $50 \mathrm{mM}$ citrate (or acetate) buffer ( $\mathrm{pH} 2.5$ to 5.5), $100 \mathrm{mM}$ phosphate buffer ( $\mathrm{pH} 6.5$ to 7.5 ) and $25 \mathrm{mM}$ borate buffer ( $\mathrm{pH} 8.5$ to 10.5). The reaction of dinitrosalicylic acid (DNSA) with known amount of xylose at different pHs was also carried out to check the sensitivity of the DNSA assay to pHs. The effect of temperature on the reaction was assessed by incubating the reaction 
mixtures $(\mathrm{pH} 3.5)$ at different temperatures in the range of 30 to $100^{\circ} \mathrm{C}$. Thermostability was monitored by incubating the enzyme at $\mathrm{pH} 3.5$ for the specified period at different temperatures followed by rapid cooling in ice and carrying out the routine assay at $50^{\circ} \mathrm{C}$ and $\mathrm{pH} 3.5$. The enzyme blanks and substrate blanks were similarly treated at respective $\mathrm{pHs}$ and temperatures for the same length of time and the absorbance was subtracted from that of reaction mixture to arrive at the actual enzyme activity.

\section{Purification of enzyme}

The crude culture filtrate was brought to $50-80 \%$ saturation with ammonium sulfate. The pellet obtained after centrifugation was suspended in a minimum volume of $50 \mathrm{mM}$ acetate buffer $(\mathrm{pH} 4.5)$ and loaded on a $130 \mathrm{ml}$ bed volume Sephadex G-100 column at a flow rate of $20 \mathrm{ml} \mathrm{h}^{-1}$. The protein was eluted with acetate buffer and $3 \mathrm{ml}$ fractions were collected. The fractions were monitored at $280 \mathrm{~nm}$ for protein and assayed as above for xylanase activity. The active fractions were pooled and concentrated by saturating to $80 \%$ with ammonium sulphate. All the above operations were carried out at $4^{\circ} \mathrm{C}$ in a cold room.

\section{Gel electrophoresis}

Polyacrylamide gel electrophoresis on native gels (10\% separating gels) was carried out in Tris-glycine buffer as described by Sambrook et al. [26] and the gels subjected to silver staining to visualize the protein bands.

For in situ detection of the enzyme, electrophoresis was carried out at $8^{\circ} \mathrm{C}$ on native composite gels of $10 \%$ polyacrylamide containing $1 \%$ xylan. The gels were then incubated in $50 \mathrm{mM}$ acetate buffer $\left(\mathrm{pH} \mathrm{4.5)}\right.$ for $30 \mathrm{~min}$ at $50^{\circ} \mathrm{C}$. After a further incubation for $30 \mathrm{~min}$ (at room temperature) in a $0.1 \%$ Congo red solution, the gels were destained in $1 \mathrm{M} \mathrm{NaCl}$ until clearance bands of xylanase activity were obtained [20]. We found that the bands were more prominent when the gels were finally transferred into $50 \mathrm{mM}$ acetate buffer $(\mathrm{pH} 4.5)$ for a few minutes. 


\section{Estimation of molecular weight}

Gel filtration of the protein standards alcohol dehydrogenase (150 kDa), bovine serum albumin (67 kDa), carbonic anhydrase (29 kDa), ribonuclease A (13.7 $\mathrm{kDa})$ and cytochrome $C(12.4 \mathrm{kDa})$ was carried out on the Sephadex G-100 column as described above. The void volume was calculated using blue dextran as marker and the calibration curve was prepared .

All the chemicals used in this study were either from Sigma Chemical Co. (St Louis, MO, USA) or of analytical grade from other reputed companies.

\section{Pulp treatment and determination of kappa number}

The pulp from sugarcane after extraction of sugar is called sugarcane bagasse and is used alone or mixed with wood chips for making paper. The screened, unbleached pulp from sugarcane bagasse (10 \% consistency) was incubated with crude culture filtrate at a ratio of $10 \mathrm{~g}$ pulp to $100 \mathrm{ml}$ enzyme (containing 58 $U$ of xylanase, $0.32 U$ of $\alpha$-L-arabinofuranosidase and $26 U \beta$-D-xylosidase activity) at $55^{\circ} \mathrm{C}$ for $1 \mathrm{~h}$. After incubation, the pulp suspension was filtered through a Whatman No.1 filter paper and air-dried. The delignification was measured as change in kappa number which is indicative of the extent of delignification and bleachability of the pulp. The kappa number is the volume of

$0.1 \mathrm{~N}$ potassium permanganate solution consumed by $1 \mathrm{~g}$ of moisture-free pulp under the conditions described in the standard procedure of TAPPI (Technical Association of Paper and Pulp Industries) Test method T236-cm-85 [1]. The kappa number $\times 0.15$ gives the percentage of residual lignin.

\section{Results}

Five marine fungi out of 6 screened showed substantial alkaline xylanase activity (Table 1). Out of these, the isolates \# 3, 9 and 289 showed xylanase activity when grown in a variety of xylan-containing substrates (Table 2). The crude enzyme preparation from the high xylanase-producing isolate \# 3 showed optimum activity at $\mathrm{pH} 3.5$ with a second peak of activity at $\mathrm{pH} 8.5$ where about $40 \%$ of the activity was measurable (Fig. 1). There was no effect of pHs on 
estimation of reducing sugars by the DNSA assay. The optimum temperature for the enzyme activity was $50^{\circ} \mathrm{C}$ and a second peak of activity was at $90^{\circ} \mathrm{C}$ when measured at $\mathrm{pH} 3.5$ whereas when assayed at $\mathrm{pH} 8.5$, maximum activity was observed at $80^{\circ} \mathrm{C}$ (Fig. 2). The activation energy up to $50^{\circ} \mathrm{C}$ was about $16 \mathrm{~kJ}$ $\mathrm{mol}^{-1}$ when the assay was carried out at $\mathrm{pH} 3.5$. Thermostability studies in the absence of substrate showed that the enzyme retained $60-65 \%$ of its activity after $1-4 \mathrm{~h}$ incubation at $55^{\circ} \mathrm{C}$ (Fig. 3). At $60^{\circ} \mathrm{C}$ it retained only $28 \%$ of the activity at the end of $2 \mathrm{~h}$ and incubation at $70^{\circ} \mathrm{C}$ inactivated the enzyme within $1 \mathrm{~h}$.

Xylanase activity of isolate \# 9 was optimum at $\mathrm{pH} 4.5$ with another peak at pH 8.5 (Fig. 1). The optimum temperature for the activity was at $50^{\circ} \mathrm{C}$ (Fig. 4). Thermostability of the enzyme showed that only $<40 \%$ of the maximum activity was retained between $1-3 \mathrm{~h}$ incubation at $55^{\circ} \mathrm{C}$ (Fig. 5).

As isolate \# 3 , obtained from mangrove detritus showed the best thermostability, it was studied further. Xylanase production was maximum at 15 ppt salinity which is the normal salinity in its natural environment (Fig. 6). About $95-98 \%$ of conidia of this fungus germinated within $6 \mathrm{~h}$ in $1 \%$ glucose solution prepared with half-strength as well as full strength sea water and also in distilled water. The fungal biomass in basal medium prepared with distilled water, halfstrength and full-strength sea water was 99,87 and $157 \mathrm{mg}$ respectively (dry weight in $20 \mathrm{ml}$ medium on day 7). It also showed good growth on plain powdered sugarcane bagasse suspended in distilled water or half-strength seawater.

The crude culture filtrate of the isolate \# 3 was tested for its biobleaching potential. The culture filtrate of this isolate grown on oat spelts xylan or sugarcane bagasse containing $580 \mathrm{U} \mathrm{L}^{-1}$ of enzyme could bleach sugarcane bagasse pulp by a $60 \mathrm{~min}$ treatment at $55^{\circ} \mathrm{C}$, resulting in a $30 \%$ reduction in chlorine consumption and a 10 point reduction in the kappa numbers (trials conducted independently by Pudumjee Paper Mills Ltd., Pune and Seshasayee Paper Mills Pvt. Ltd., Chennai, India). The unbleached bagasse showed 48 kappa number and the enzyme-treated pulp showed a kappa number of 38 . The 
drop in kappa number after biobleaching indicates reduction in chlorine consumption during further bleaching of the pulp.

No cellulase activity either on CMC-cellulose or filter paper was detected in culture filtrate from isolate \# 3 . $\beta$-xylosidase activity in the filtrate was optimum at $\mathrm{pH} 4$ and $70^{\circ} \mathrm{C}$ with about $260 \mathrm{U} \mathrm{L}^{-1}$ and $\alpha$-arabinofuranosidase activity was optimum at $\mathrm{pH} 4$ and $60^{\circ} \mathrm{C}$ with about $50 \mathrm{U} \mathrm{L}^{-1}$ produced in the filtrate of a 4-day old culture. About 79 and $76 \%$ of the xylanase activity could be detected when the enzyme was assayed in the presence of 0.1 and $0.2 \%$ black liquor respectively.

Partial purification of xylanase from isolate \# 3

Ammonium sulfate fractionation of the culture filtrate yielded maximum xylanase activity at $50-80 \%$ saturation (Table 3 ). Two bands of xylanase activity in the crude (lane $1 \& 2$ ) and 50-80\% ammonium sulfate fraction (lane $4 \& 5$ ) and only one band of activity (lane 3) in $0-35 \%$ fraction (Fig.7) were seen on polyacrylamide gel containing $1 \%$ xylan.

The elution profile of the $50-80 \%$ ammonium sulfate fraction subjected to column chromatography on a Sephadex G-100 matrix showed three distinct protein peaks, two of which had xylanase activity (Fig. 8). The active fractions in each peak were pooled, concentrated by saturating to $80 \%$ with ammonium sulfate and designated Xyl I and Xyl II. The Xyl I and Xyl II fractions showed specific activities of 393 and $2457 \mathrm{U} \mathrm{mg}^{-1}$ protein, respectively (Table 3).

The xylanase-active peaks on Sephadex G-25 matrix were found to correspond to molecular weights of 18 and $13 \mathrm{kDa}$, respectively. These results indicate successful separation of two distinct xylanases. Purification by almost 104-fold for Xyl I and 647-fold for Xyl II activity with respect to the crude extract was achieved.

\section{Degradation products of xylanase activity}

The degradation products of oat spelts xylan incubated with xylanase from 50$80 \%$ ammonium sulfate fractions for $30 \mathrm{~min}$ at $50^{\circ} \mathrm{C}$ and $80^{\circ} \mathrm{C}$ at $\mathrm{pH} 3.5$ and 8.5 
were identified by paper chromatography as a mixture of xylose, xylobiose, xylotriose, xylotetrose and xylopentose (Fig. 9) confirming the xylanase to be an endoxylanase type. The presence of xylose also indicated $\beta$-xylosidase activity.

\section{Discussion}

The best xylanase-producing isolates were not obligate marine but facultative marine fungi ( $A$. niger and A.ustus). This was not surprising as many terrestrial species of fungi appear to have adapted themselves to marine conditions and play an important role therein. Such "facultative marine fungi" [17] have been associated with coastal marine plant litter ecosystems [6, 10, 25]. Novel secondary metabolites have been isolated from marine isolates of terrestrial species of fungi [15]. Our present studies indicate that facultative marine fungi may produce enzymes with unique properties. The facultative marine nature of the strain of Aspergillus niger, NIOCC isolate \# 3, obtained from mangrove leaf detritus after rigorous surface sterilization is further proved by the fact that the conidia showed germination in sea water and produced higher fungal biomass in sea water medium. Xylanase production was also seen in media prepared with natural sea water.

A number of species of Aspergillus isolated from terrestrial habitats are known to produce xylanase in acidic media and also show activity under acidic assay conditions $[4,27]$. Our marine isolate of $A$. niger produced xylanase in acidic as well as in alkaline media and the enzymes thus produced showed good activity at both acidic and alkaline $\mathrm{pH}$. An extremely high specific activity (2457 $\mathrm{U}$ $\mathrm{mg}^{-1}$ protein for Xyl II) appears to be a novel feature of the enzyme from this isolate [24]. High specific activity has also been reported for a xylanase from Aureobasidium pullulans (de Barry) Arnaud, which produces low molecular

weight extracellular xylanase having a specific activity of $2000 \mathrm{U} \mathrm{mg}^{-1}$ protein [18].

Aspergillus niger isolated from a terrestrial source was reported to produce endoxylanases I and II with low molecular weights of ca. $13 \mathrm{kDa}$ [11]. Our strain of $A$. niger produced two endoxylanases having molecular masses of 
13 and $18 \mathrm{kDa}$. The two endoxylanases of the terrestrial isolate of $A$. niger showed only one temperature optimum of $45^{\circ} \mathrm{C}$ and $\mathrm{pH}$ optima of 6.0 and 5.5 [11]. Xylanase activity in the crude culture filtrate of our isolate showed $\mathrm{pH}$ optimum around 3.5 with a second peak of activity at $\mathrm{pH} 8.5$. When assayed at $\mathrm{pH} 3.5$ it showed a temperature optimum at $50^{\circ} \mathrm{C}$ and a second peak of activity at $90^{\circ} \mathrm{C}$. At $\mathrm{pH} 8.5$ the enzyme had optimum activity at $80^{\circ} \mathrm{C}$. Up to $40^{\circ} \mathrm{C}$ the energy of activation for xylanase I was $30.4 \pm 12.0 \mathrm{~kJ} \mathrm{~mol}^{-1}$ while that of xylanase II was $38.8 \pm 8.6 \mathrm{~kJ} \mathrm{~mol}^{-1}$ for the terrestrial isolate of $A$. niger [11] while for our isolate, the activation energy up to $50^{\circ} \mathrm{C}$ was only about $16 \mathrm{~kJ} \mathrm{~mol}^{-1}$. The terrestrial isolate did not produce xylose on hydrolysis of xylan. On the contrary, the $50-80 \%$ ammonium sulfate fraction on reaction with oat spelts xylan yielded xylose, besides xylobiose, xylotriose, xylotetrose and xylopentose by hydrolysis of oat spelts xylan, confirming the presence of endoxylanase [20]. Xylose production might also be due to the activity of $\beta$-xylosidase in our marine isolate.

The stability of the enzyme for nearly $4 \mathrm{~h}$ at $55^{\circ} \mathrm{C}$ (Fig. 3)) suggests that a crude enzyme solution could be used directly for bleaching of the cooked paper pulp without substantially bringing down the temperature of the pulp. Crude culture filtrate of another strain of $A$. niger was reported to bleach Kraft pulp by virtue of its xylanolytic enzymes [8]. Thermomyces lanuginosus which produces cellulase-free exo-and endo-xylanase could bring down kappa number of hardwood pulp from 20 to 17 and 13 respectively, when $100 \mathrm{U}$ and $300 \mathrm{U}$ of xylanase $\mathrm{g}^{-1}$ pulp were used [29]. About $50 \mathrm{U}$ of xylanase from Thermomonospora fusca reduced the kappa number of softwood Kraft pulp from 18.5 to 13.4 within $2 \mathrm{~h}$ at $70^{\circ} \mathrm{C}$ [5]. About $100 \mathrm{ml}$ of the crude culture filtrate of our strain having $58 U$ of endoxylanase, $26 U$ of $\beta$-xylosidase and $0.32 U$ of $\alpha$-Larabinofuranosidase activities, on incubation with $10 \mathrm{~g}$ of sugarcane bagasse pulp reduced the kappa number from 48 to 38 within $1 \mathrm{~h}$ of incubation at $55^{\circ} \mathrm{C}$. A crude culture filtrate having a xylan-degrading enzyme system (devoid of cellulase activity) that could be used in the biobleaching process would eliminate steps involved in purification of the enzyme(s), thus bringing down the cost involved in their production and increase the economic viability. 
Presence of multiple xylanases has been reported in a number of fungal and bacterial isolates from terrestrial sources [30]. A species of Cephalosporium produced two xylanases varying in their pls, $\mathrm{K}_{\mathrm{m}}$ constants and molecular weights [16]. Similarly, a Bacillus species also produced two xylanases differing in their temperature and $\mathrm{pH}$ optima [12]. Presence of two $\mathrm{pH}$ and temperature optima, differing specific activity of the two peaks of xylanase activity separated on gel filtration suggest the presence of multiple xylanases in our isolate NIOCC \# 3 too. The total yield of Xyl I and Xyl II separated by column chromatography was not very high, largely because the focus was on elimination of other minor xylanase activities in the ammonium sulphate fractionation step. Such situations are commonly reported in the literature $[20,11]$ wherein multiplicity of xylanase activity has been encountered.

We have earlier reported fungi from marine habitats capable of producing lignin-modifying enzymes [22,23]. The co-production of endoxylanase, $\beta-D-$ xylosidase and $\alpha-L-$ arabinofuranosidase in a cellulase-free enzyme system by isolate \# 3 from marine habitats with a potential in biobleaching, indicates the importance of marine fungi in biotechnological applications. Although the xylanase production is not very high in this isolate, due to its novel properties it is worthwhile to overproduce the enzyme through various approaches.

\section{Acknowledgements}

We thank Ms Gauri Rivonkar and Ms Shilpa Kamat for the excellent laboratory assistance rendered at N.I.O. Our grateful thanks to Pudumjee Paper Mills Ltd., Pune, India and Seshasayee Paper Mills, Chennai for conducting bleaching trials with our enzyme. This is NIO's contribution No. 


\section{References}

1. Anonymous (1988) Kappa number of pulp-T 236- cm- 85 In TAPPI Test Methods, TAPPI Press, Atlanta, GA, Vol. 1. pp 1-3

2. Ali M, Sreekrishnan TR (2001) Aquatic toxicity from pulp and paper mill effluents: a review. Adv Environ Res 5: 175-196

3. Anthony T, Chandra Raj K, Rajendran A, Gunasekaran P (2003) High molecular weight cellulase-free xylanase from alkali-tolerant Aspergillus fumigatus AR1. Enz Microbial Technol 32: 647-654

4. Biswas SR, Jana SC, Mishra AK, Nanda G (1990) Production, purification and characterization of xylanase from a hyperxylanolytic mutant of Aspergillus ochraceus. Biotechnol Bioeng 35: 244-251

5. Casimir-Schenkel J, Davis S, Fiechter A, Gygin B, Murray E, Perrolax J, Zimmermann W (1995) Pulp bleaching with thermostable xylanase of Thermomonospora fusca. US Patent No. 5407827, 18.04.95

6. Cundell AM, Brown MS, Stanford R, Mitchell R (1979) Microbial degradation of Rhizophora mangle leaves immersed in the sea. Estuar Coastal Shelf Sci 9: $281-286$

7. Domsch KH, Gams W, Anderson TH (1980) Compendium of soil fungi. Academic Press, London.

8. Duarte JC, Maximo C, Dias A, Costa-Ferreira M, Vasconcelos L, Morgado MJ (1993) Biobleaching of kraft pulp by Aspergillus niger xylanolytic enzymes. Proc Symp on Lignin: biodegradation and transformation. Lisbon, Portugal, 211-214

9. Eriksson KE (1993) Concluding remarks: Where do we stand and where are we going? Lignin biodegradation and practical utilization. J Biotech 30: 149158

10. Fell JW, Newell SY (1981) Role of fungi in carbon nitrogen immobilization in coastal marine plant litter systems. In: Wicklow, DT, Carroll GC (eds) The Fungal Community. Marcel Dekker Inc., New York, pp. 665-678

11. Frederick MM, Kiang CH, Frederick JR, Reilly PJ (1985) Purification and characterization of endo-xylanases from Aspergillus niger. I. Two isozymes active on xylan backbones near branch points. Biotechnol. Bioeng 27: 525532

12. Gessesse A (1998) Purification and properties of two thermostable alkaline xylanases from an alkaliphilic Bacillus sp. Appl Environ Microbiol 64:35333535 
13. Ghosh TK (1987) Measurement of cellulase activities. Pure Appl Chem 59: 257-268

14. Haack S (1992) Description of a new species of Cytophaga and characterization of its xylan-degrading enzyme system. Ph. D. thesis. Michigan State University, East Lansing, MI, USA.

15. Jensen PR, Fenical W (1999) Exploring marine fungi as a source of novel pharmaceutical leads. Abstract in The $7^{\text {th }}$ International Marine and Fresh water Mycology Symposium, Hong Kong, p. 55

16. Kang MK, Maeng PJ, Rhee YA (1996) Purification and characterization of two xylanases from alkalophilic Cephalosporium sp. Strain RYM-202. Appl Environ Microbiol 62: 3480-3482

17. Kohlmeyer J, Kohlmeyer E (1979) Marine Mycology, The Higher Fungi. Academic Press, New York, pp. 690

18. Leathers TD (1986) Color variants of Aureobasidium pullulans overproduce xylanase with extremely high specific activity. Appl Environ Microbiol 52: 1026-1030

19. Lowry OH, Rosebrough NJ, Farr AL, Randall RJ (1951) Protein measurement with Folin Phenol reagent. J Biol Chem 193: 265-275

20. Morales PJ, Madarro J, Perez-Gonzalez A, Sendra JM, Pinaga F, Flors A (1993) Purification and characterization of alkaline xylanases from Bacillus polymyxa. Appl Environ Microbiol 59: 1376-1382

21. Nakamura S, Wakabayashi K, Nakai, R, Aono R, Horikoshi K (1993) Purification and some properties of an alkaline xylanase from alkaliphilic Bacillus sp. Strain 41M-1. Appl Environ Microbiol 59: 2311-2316

22. Raghukumar C, Raghukumar S, Chinnaraj A, Chandramohan D, D'Souza TM, Reddy CA (1994) Laccase and other lignocellulose modifying enzymes of marine fungi isolated from the coast of India. Bot Mar 37: 515-523

23. Raghukumar C, D'Souza TM, Thorn RG, Reddy CA (1999) Lignin-modifying enzymes of Flavodon flavus, a basidiomycete isolated from a coastal marine environment. Appl Environ Microbiol 65: 2103-2111

24. Raghukumar C, Muraleedharan UD (2000) A process for production of xylan-degrading enzymes. Indian Patent No. NF 30/2000, 31.03.2000 
25. Raghukumar S, Sharma S, Raghukumar C, Sathe-Pathak V, Chandramohan D (1994) Thraustochytrid and fungal component of marine detritus. IV. Laboratory studies on decomposition of leaves of the mangrove Rhizophora apiculata Blume J Exp Mar Biol Ecol 175: 227-242.

26. Sambrook J, Fritsch EF, Maniati T (1989) Molecular Cloning. A Laboratory Manual. $2^{\text {nd }}$ edn. Cold Spring Harbor Laboratory Press, USA.

27. Smith DC, Wood TM (1991) Xylanase production by Aspergillus awamori. Development of a medium and optimization of the fermentation parameters for the production of extracellular xylanase and $\beta$-xylosidase while maintaining low protease production. Biotechnol Bioeng 38: 883-890

28. Srinivasan MC, Rele MV (1995) Cellulase-free xylanases from microorganisms and their application to paper and pulp biotechnology: an overview. Indian J Microbiol 35: 93-101

29. Wizani W, Esterbauer H, Gomes J (1993) Preparation of xylanase by cultivating Thermomyces lanuginosus DSM 5826 in a medium containing corn cobs. US Patent No. 5183753 of 02.02.1993

30. Wong KK, Tan Y, Saddler JN (1988) Multiplicity of $\beta-1,4-x y l a n a s e$ in microorganisms: function and applications. Microbiol Rev 52: 305-317 
Table 1. Xylanase production by marine fungi $\left(\mathrm{U} \mathrm{L}^{-1}\right)$

\begin{tabular}{|c|c|c|c|c|c|c|}
\hline \multirow{2}{*}{$\begin{array}{c}\text { Isolate } \\
\#\end{array}$} & \multirow[t]{2}{*}{ Identity } & \multirow[t]{2}{*}{ Source } & \multicolumn{2}{|c|}{ Growth at $\mathrm{pH} 4.5$} & \multicolumn{2}{|c|}{ Growth at $\mathrm{pH} 8.5$} \\
\hline & & & $\begin{array}{c}\text { Assayed } \\
\text { at } \mathrm{pH} \\
3.5\end{array}$ & $\begin{array}{c}\text { Assayed } \\
\text { at } \mathrm{pH} \\
8.5\end{array}$ & $\begin{array}{c}\text { Assayed } \\
\text { at } \mathrm{pH} \\
3.5\end{array}$ & $\begin{array}{c}\text { Assayed } \\
\text { at } \mathrm{pH} \\
8.5\end{array}$ \\
\hline 3 & $\begin{array}{c}\text { Aspergillus } \\
\text { niger }\end{array}$ & $\begin{array}{c}\text { Mangrove } \\
\text { detritus }\end{array}$ & $737 \pm 13$ & $857 \pm 27$ & $745 \pm 15$ & $864 \pm 10$ \\
\hline 289 & $\begin{array}{l}\text { Unidentified } \\
\text { ascomycete }\end{array}$ & $\begin{array}{l}\text { Mangrove } \\
\text { detritus }\end{array}$ & $613 \pm 4$ & $751 \pm 19$ & $594 \pm 18$ & $654 \pm 21$ \\
\hline 312 & $\begin{array}{l}\text { Flavodon } \\
\text { flavus }\end{array}$ & $\begin{array}{c}\text { Decaying } \\
\text { seagrass } \\
\text { from a coral } \\
\text { lagoon } \\
\end{array}$ & $177 \pm 18$ & $144 \pm 10$ & $207 \pm 15$ & $144 \pm 17$ \\
\hline 313 & $\begin{array}{c}\text { Gongronella } \\
\text { sp }\end{array}$ & $\begin{array}{l}\text { Mangrove } \\
\text { sediment }\end{array}$ & $282 \pm 10$ & $237 \pm 16$ & $351 \pm 20$ & $237 \pm 30$ \\
\hline 321 & $\begin{array}{l}\text { Halosarpheia } \\
\text { ratnagiriensis }\end{array}$ & $\begin{array}{c}\text { Mangrove } \\
\text { wood }\end{array}$ & $57 \pm 10$ & $60 \pm 5$ & $45 \pm 7$ & $69 \pm 9$ \\
\hline 9 & $\begin{array}{l}\text { Aspergillus } \\
\text { ustus }\end{array}$ & $\begin{array}{l}\text { Calcareous } \\
\text { sediment } \\
\text { from } 860 \mathrm{~m} \\
\text { depth in the } \\
\text { Arabian Sea }\end{array}$ & $2924 \pm 40$ & $1533 \pm 27$ & nd & nd \\
\hline
\end{tabular}

$\mathrm{Nd}=$ no data. $\mathrm{U}=$ unit of enzyme expressed as $\mu \mathrm{mol}$ xylose equivalent released $\min ^{-1}$. 
Table 2. Effect of substrate and salinity on the production of xylanase $\left(\mathrm{U} \mathrm{L}^{-1}\right)$ by selected isolates

\begin{tabular}{|c|c|c|c|}
\hline Substrate & Isolate \# & $\begin{array}{l}\text { Basal medium } \\
\text { prepared with } \\
\text { distilled water }\end{array}$ & $\begin{array}{c}\text { Basal medium } \\
\text { prepared with } \\
\text { half-strength sea } \\
\text { water* }^{*}\end{array}$ \\
\hline \multirow{3}{*}{$\begin{array}{l}\text { Sugarcane } \\
\text { bagasse }\end{array}$} & 3 & $1356 \pm 178$ & $1245 \pm 377$ \\
\hline & 9 & $1295 \pm 101$ & $1131 \pm 97$ \\
\hline & 289 & $1345 \pm 77$ & $1395 \pm 177$ \\
\hline \multirow{3}{*}{$\begin{array}{c}\text { Commercial } \\
\text { breakfast oats }\end{array}$} & 3 & $958 \pm 75$ & $625 \pm 65$ \\
\hline & 9 & $789 \pm 79$ & $534 \pm 50$ \\
\hline & 289 & $702 \pm 23$ & $709 \pm 37$ \\
\hline \multirow{3}{*}{$\begin{array}{c}\text { Oat spelts } \\
\text { xylan }\end{array}$} & 3 & $1624 \pm 7$ & $1100 \pm 41$ \\
\hline & 9 & $876 \pm 45$ & $1297 \pm 25$ \\
\hline & 289 & $699 \pm 32$ & $729 \pm 41$ \\
\hline \multirow{3}{*}{$\begin{array}{l}\text { Birchwood } \\
\text { xylan }\end{array}$} & 3 & $1645 \pm 58$ & $1369 \pm 138$ \\
\hline & 9 & $790 \pm 101$ & $502 \pm 87$ \\
\hline & 289 & $753 \pm 85$ & $637 \pm 49$ \\
\hline
\end{tabular}

$\mathrm{U}=$ unit of enzyme expressed as $\mu \mathrm{mol}$ xylose equivalent released $\min ^{-1} ;{ }^{*}=$ equivalent to 15 ppt salinity which is the normal salinity in the mangrove ecosystem. 
Table 3. Ammonium sulphate fractionation of culture filtrate and further purification of xylanase from the isolate \# 3.

\begin{tabular}{|c|c|c|}
\hline Fraction & $\begin{array}{c}\text { Total activity } \\
\text { (U) }\end{array}$ & $\begin{array}{l}\text { Specific activity } \\
\left(\mathrm{U} \text { mg protein }{ }^{-1}\right)\end{array}$ \\
\hline Crude culture filtrate & 48.8 & 3.8 \\
\hline $0-35 \%$ & 15.3 & 1.9 \\
\hline $35-50 \%$ & 2.6 & 5.8 \\
\hline $50-80 \%$ & 20.1 & 18.9 \\
\hline $80-90 \%$ & 2.0 & 5.8 \\
\hline $\begin{array}{c}\text { Sephadex G-100 } \\
\text { fraction (Xyl I) }\end{array}$ & 6.1 & 393.3 \\
\hline $\begin{array}{c}\text { Sephadex G-100 } \\
\text { fraction (Xyll I) }\end{array}$ & 2.4 & 2457.0 \\
\hline
\end{tabular}




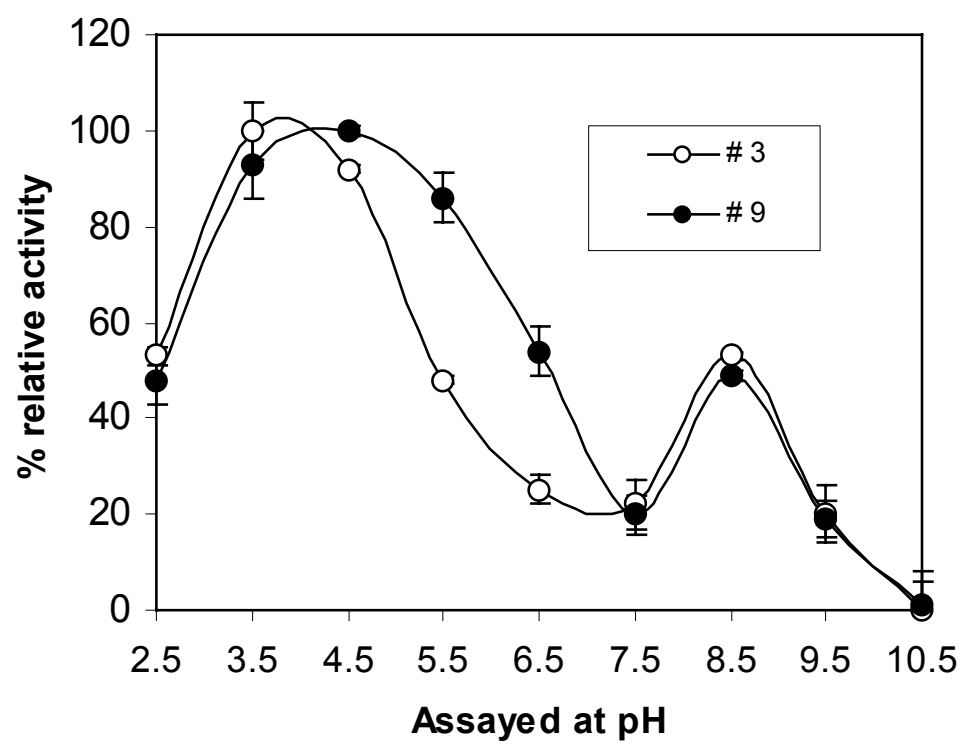

Fig. 1. Effect of assay $\mathrm{pH}$ on xylanase activity of culture filtrates from isolates \# 3 and 9. The enzyme was assayed at $50^{\circ} \mathrm{C}$ in a range of $\mathrm{pH} 2.5$ to 10.5 as described in Materials and Methods. Bars show standard deviation.

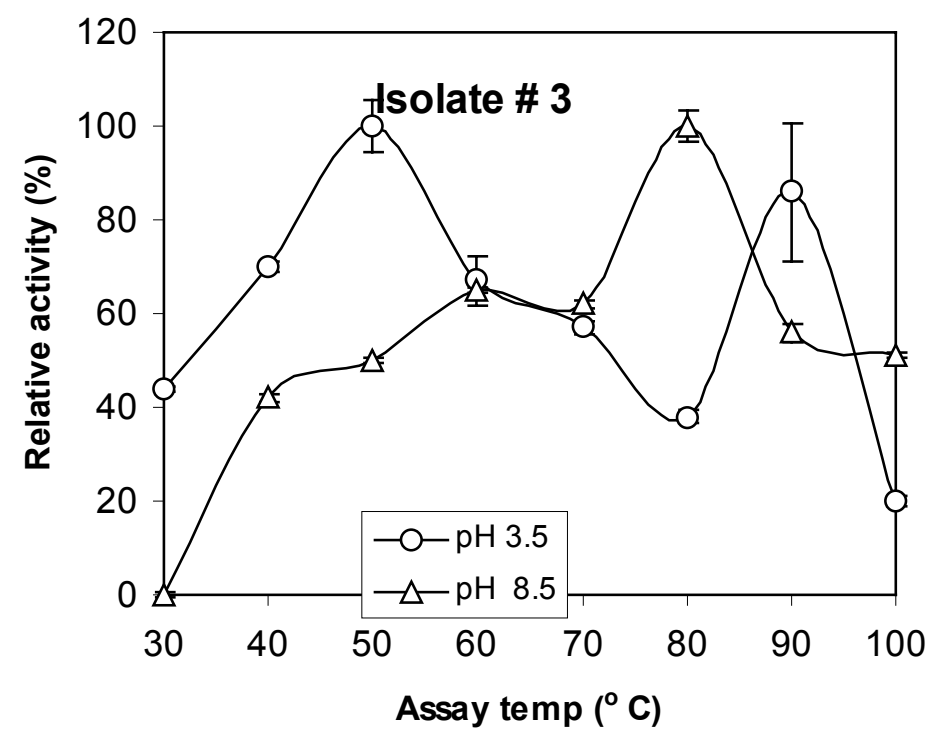

Fig. 2. Effect of assay temperature on xylanase activity in culture filtrate of isolate \#3. The enzyme activity was assayed at $\mathrm{pH} 3.5$ and 8.5 at temperatures ranging from 30 to $100 \mathrm{oC}$ for $30 \mathrm{~min}$. The enzyme blank and substrate blanks were also incubated at these temperatures and the reducing sugars released were estimated using DNSA reagent. The values for the blanks were subtracted from the reaction mixture to arrive at the enzyme activity. Bars show standard deviation 


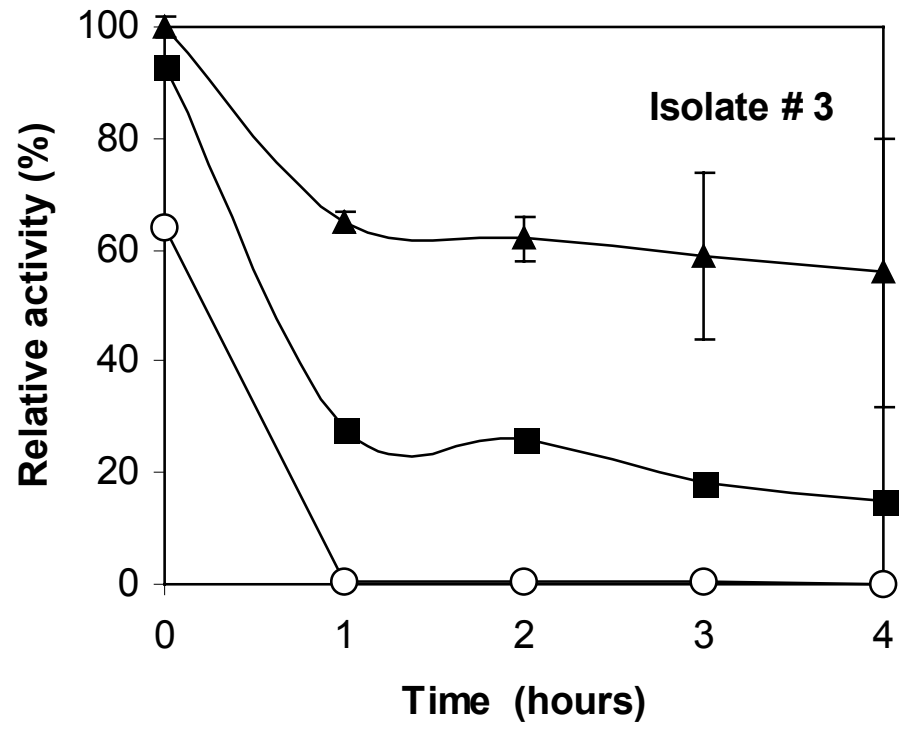

Fig. 3. Effect of temperature on xylananse stability in culture filtrate of isolate \# 3 . The filtrate was incubated at different temperatures for various time periods followed by rapid cooling and measuring the residual activity by incubating with the substrate. $\boldsymbol{\Delta}$ $550 \mathrm{C}, \boldsymbol{\square} 60 \mathrm{o}$ C, O 70o C. Bars show standard deviation.

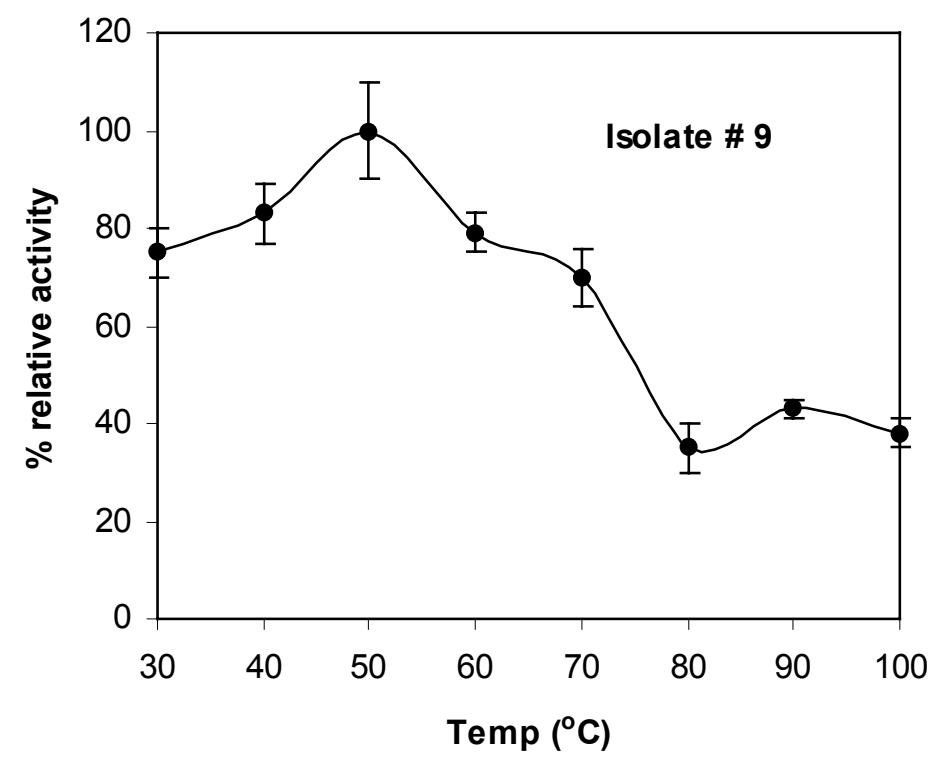

Fig. 4. Effect of assay temperature on the xylanase activity of culture filtrate the isolate \# 9. Bars show standard deviation. 


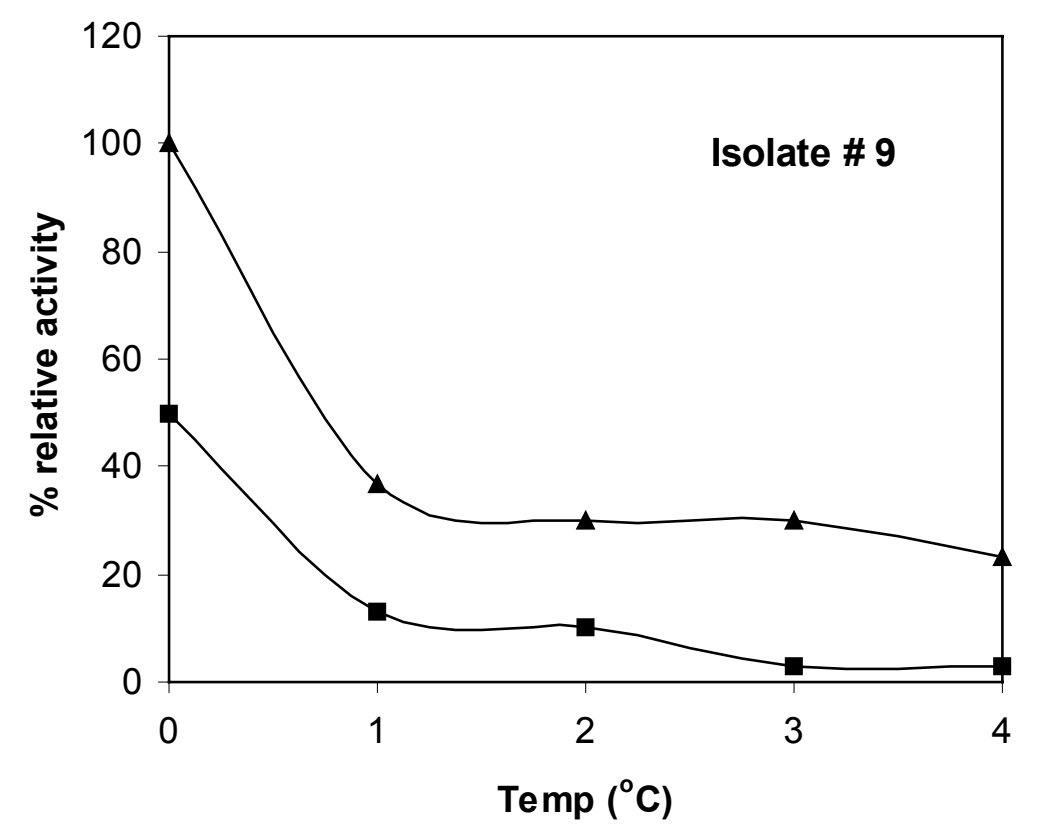

Fig. 5. Effect of temperature on xylanase stability in culture filtrate of the isolate \# 9 . The filtrate was incubated at different temperatures, $\Delta 55^{\circ} \mathrm{C}, 60^{\circ} \mathrm{C}$ for various time periods followed by rapid cooling and measuring the residual activity by incubating with the substrate and buffer at $50^{\circ} \mathrm{C}$ for $30 \mathrm{~min}$.

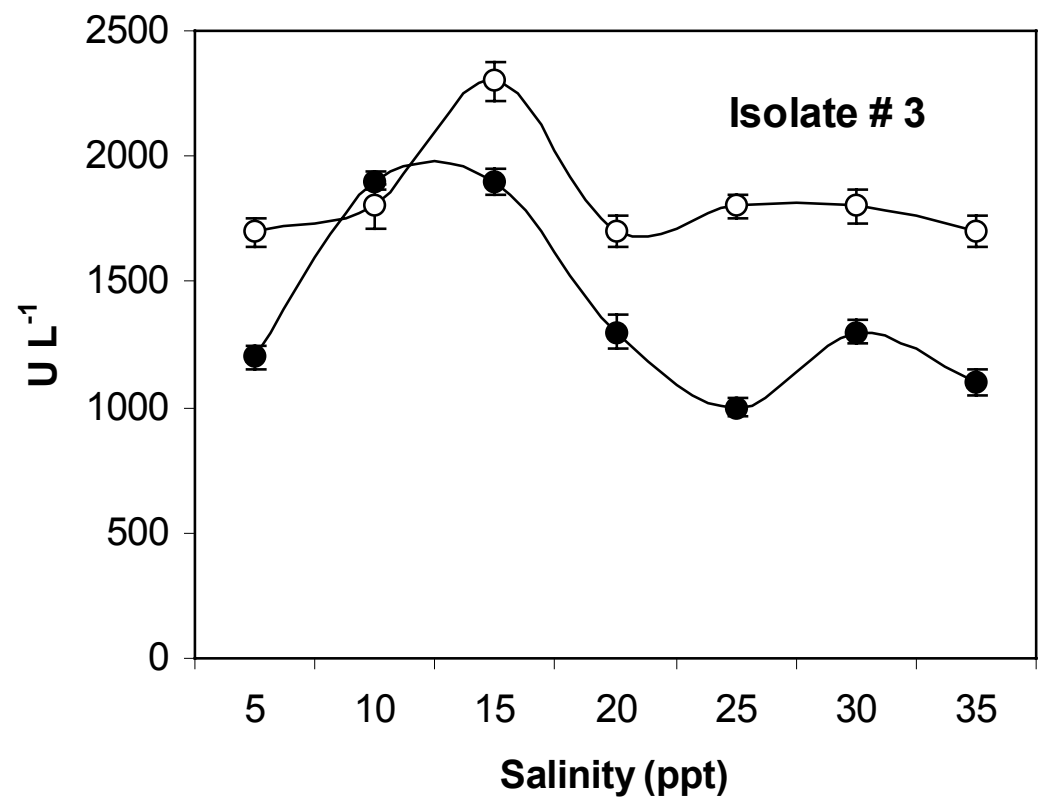

Fig. 6. Effect of salinity of the growth medium on xylanase production by isolate \# 3 when measured at $\mathrm{pH} 3.5$ at $50^{\circ} \mathrm{C}(\mathrm{O})$ and $80^{\circ} \mathrm{C}(\bullet)$. Bars show standard deviation. 


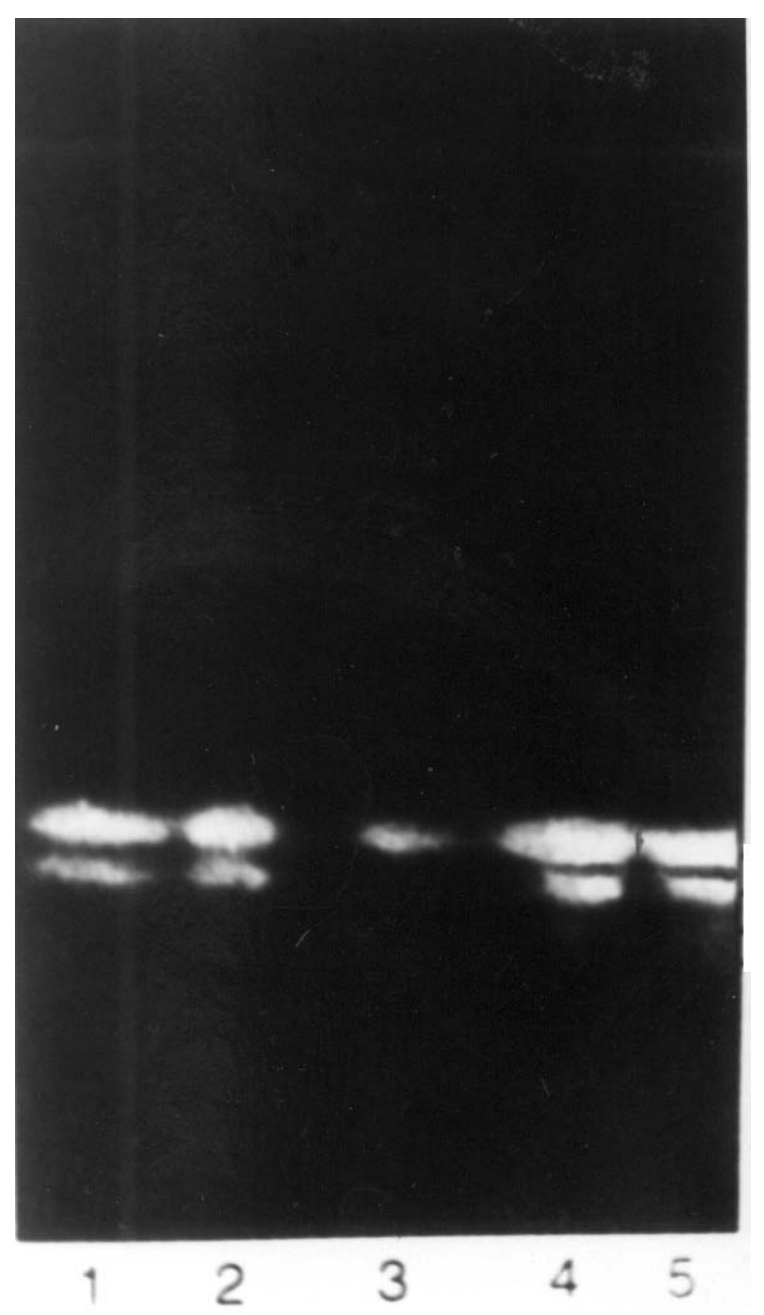

Fig. 7. In situ detection of xylanase derived from culture filtrate of isolate \#3 after nondenaturing electrophoresis on polyacrylamide gel containing oat spelt xylan. Lanes 1 \& 2: crude extract containing 78 and $156 \mu$ p protein respectively. Lane 3: $0-35 \%$ ammonium sulfate fraction, $15 \mu \mathrm{g}$ protein. Lanes 4 \& 5: $50-80 \%$ ammonium sulfate fractions containing 20 and $40 \mu \mathrm{g}$ protein respectively. The two xylanase activity bands (XyI I and Xyl II) are prominent. 


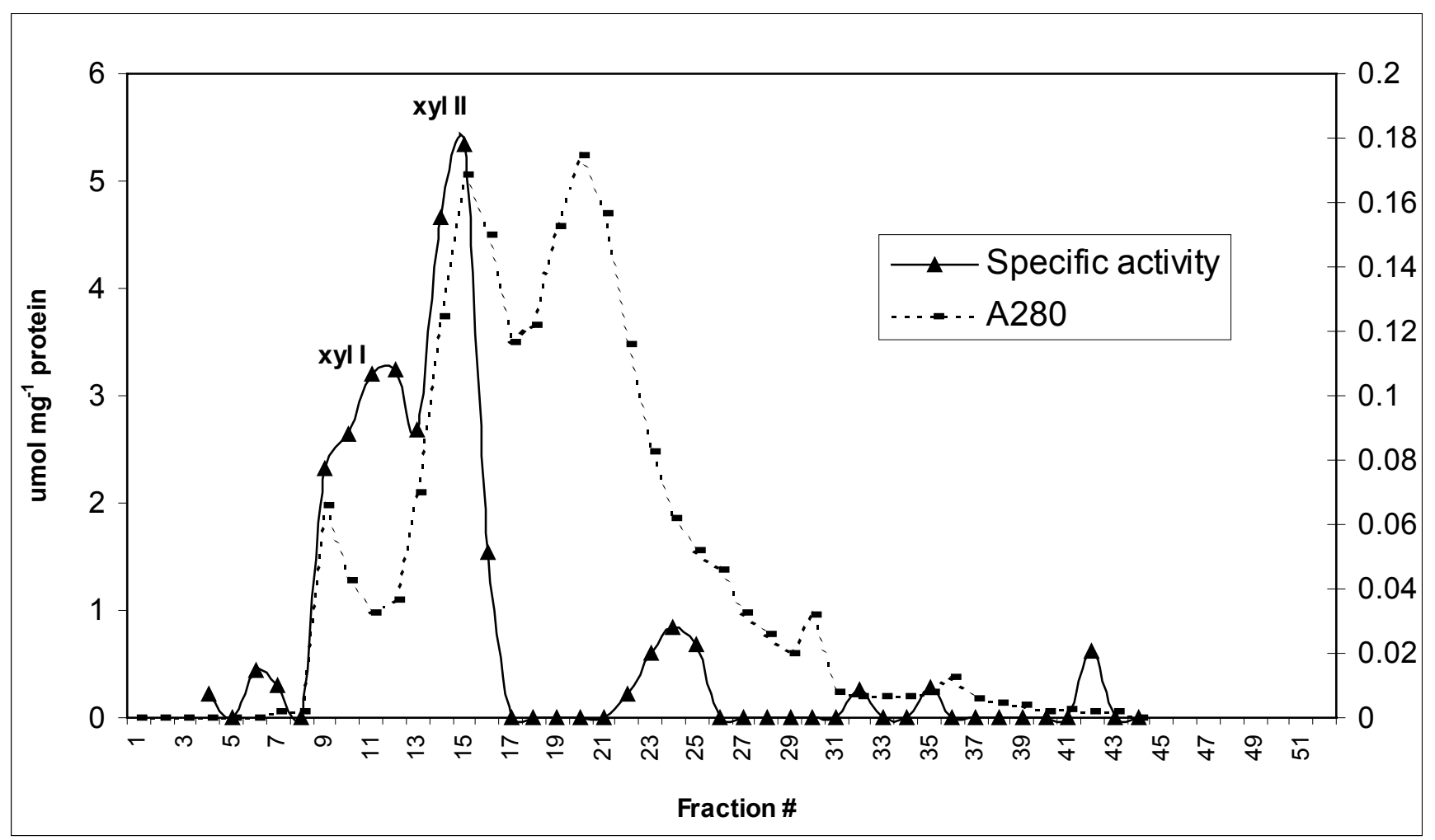

Fig. 8. Gel filtration profile of the $50-80 \%$ ammonium sulfate fraction derived from culture filtrate of isolate \#3 on Sephadex-G100 column. Assays for xylanase activity (A) and protein by $A_{280}$ measurement (----) were carried out for the $3 \mathrm{ml}$ fractions collected.

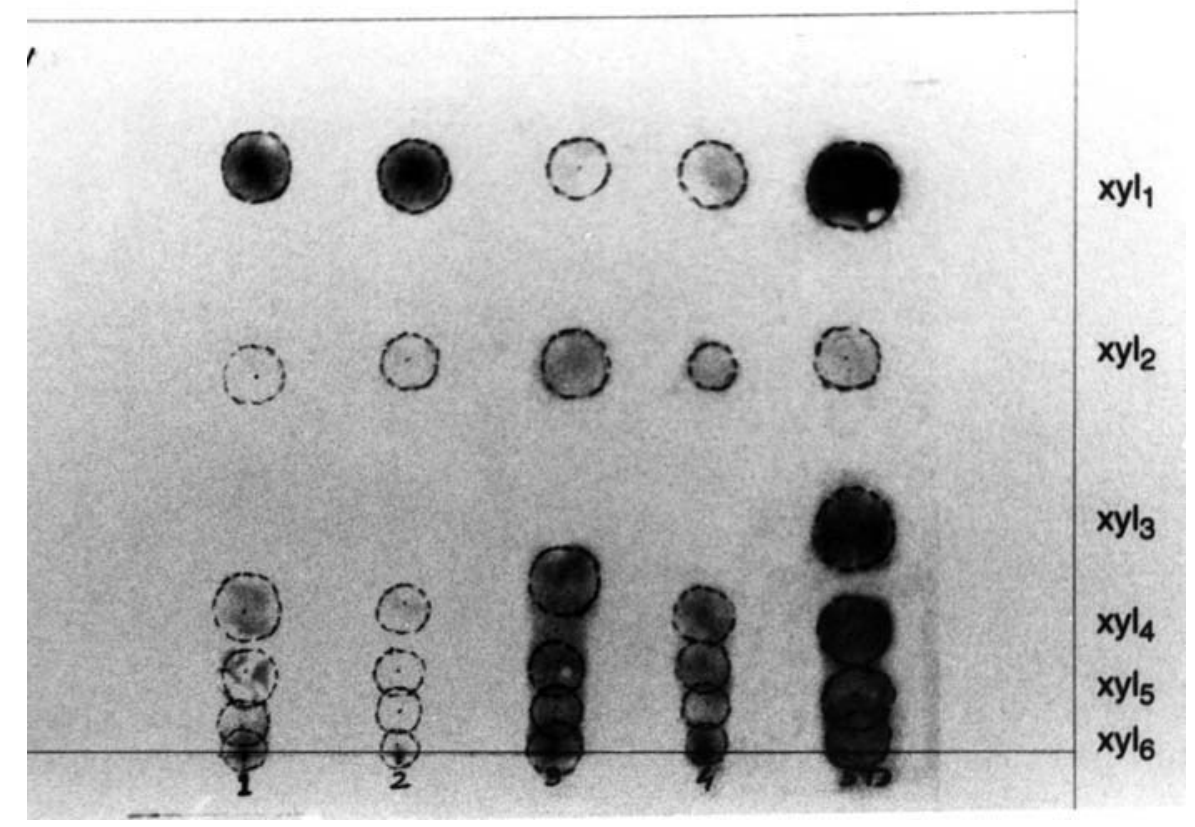

Fig. 9. Paper chromatography of the hydrolysis products of oat spelt xylan after incubation for $30 \mathrm{~min}$ with the $50-80 \%$ ammonium sulfate fraction derived from culture filtrate of isolate \#3. Lane 1; culture grown at $\mathrm{pH} 4.5$ and assayed at $\mathrm{pH} 4.5 / 50^{\circ} \mathrm{C}$; Lane 2 culture grown at $\mathrm{pH} 4.5$ and assayed at $\mathrm{pH} 4.5 / 80^{\circ} \mathrm{C}$; Lane 3 culture grown at $\mathrm{pH} 8.5$ and assayed at $\mathrm{pH}$ $8.5 / 50^{\circ} \mathrm{C}$; Lane 4 culture grown at $\mathrm{pH} 8.5$ and assayed at $\mathrm{pH} 8.5 / 80^{\circ} \mathrm{C}$. Lane 5 Standard, containing a mixture of xylose $\left(X_{1}\right)$, xylobiose $\left(X_{2}\right)$, xylotriose $\left(X_{3}\right)$, xylotetrose $\left(X_{4}\right)$, xylopentose $\left(X_{5}\right)$ and xylohexose $\left(X_{6}\right)$. 